SHORT COMMUNICATION

\title{
Dietary Micro-Nutrients Supplementation in the Ration of Transition Crossbred Cows Influences the Growth Performance and Hemato-Biochemical Parameters of Newborn Calves
}

\author{
Anil Rathor ${ }^{1,2}$, R.K. Jain ${ }^{1 *}$, M.K. Mehta ${ }^{1}$ and Anchal Keshri ${ }^{1}$ \\ ${ }^{1}$ Department of Animal Nutrition, College of Veterinary Science and A. H., Mhow, Madhya Pradesh, INDIA \\ ${ }^{2}$ Technical Manager Shree Ganesh Feed Indusrtries Raikot, Ludhiana (Punjab), INDIA \\ *Corresponding author: R K Jain; E-mail:drrkjainvet@gmail.com
}

Received: 10 Aug., 2021

Revised: 15 Sept., 2021

Accepted: 19 Sept., 2021

\begin{abstract}
The present work was planned to access the effect of dietary micronutrient supplementation to the transition crossbred cows affecting the performance of newborn calves. Twenty healthy advanced pregnant crossbred cows (average body weight 408.25 $\pm 12.93 \mathrm{~kg}$ ) reared under similar conditions were selected randomly and divided into two equal groups. Control cows fed on the existing ration while the treatment cows additionally fed with antioxidant micronutrients (trace minerals $\mathrm{Cu}$ and $\mathrm{Zn}$ with vitamin A and E) as per the recommendations. Experimental feeding was started about two months pre-partum till two months post-partum. The influence of dietary micro-nutrients supplementation in transition crossbred cows was judged by measuring birth weight, fortnightly body weight, and some haemato-biochemical parameters of their calves. The mean birth weight $(\mathrm{kgs})$ of calves was higher $(\mathrm{P}=0.06)$ in the treatment group $(34.15 \pm 0.88)$ as compared to the control group values (32.08 \pm 1.55$)$. Bodyweight at the termination of the experimental feeding though remained statistically comparable between the two groups but high in treatment $(53.25 \pm 1.67 \mathrm{~kg})$ than in the control $(49.75 \pm 1.61 \mathrm{~kg})$ group. The hematological parameters i.e. $\mathrm{Hb}(\mathrm{g} / \mathrm{dl})$ was $9.53 \pm 0.53$ and $11.03 \pm 0.70$; total leukocytes count $\left(\times 10^{3} \mathrm{~mm}^{-3}\right) 9.64 \pm 0.35$ and $9.01 \pm 0.55$ and percentages of neutrophil $34.67 \pm 1.94$ and $29.33 \pm 1.67$, lymphocyte $63.50 \pm 2.0$ and $68.83 \pm 1.89$, monocyte remained $2.00 \pm 0.68$ and $1.67 \pm 0.33 \%$ in un-supplemented and supplemented group, respectively without any significant difference between two groups. It may be concluded that supplementation of antioxidant micro-nutrients in the transition dairy cow's ration was unable to influence the growth and hemato-biochemical parameters in their calves.
\end{abstract}

\section{HIGHLIGHTS}

(0 Study focused on effect of dietary supplementation of $\mathrm{Cu}$ and $\mathrm{Zn}$ with vitamin $\mathrm{A}$ and $\mathrm{E}$ to the transition crossbred cows.

(0 Effect of dietary micronutrient supplementation of $\mathrm{Cu}$ and $\mathrm{Zn}$ with vitamin $\mathrm{A}$ and $\mathrm{E}$ did not effect birth weight, fortnightly body weight, and some haemato-biochemical parameters of calves.

Keywords: Body weights, Calves, Hematobiochemical, Micro-nutrients, Transition cows

In the Malwa region of Madhya Pradesh crossbred dairy cattle in advanced pregnancy mostly fed on leguminous straw-based ration with an inadequate quantity of imbalanced concentrate mixture without vitamin and mineral supplementation (Jain et al., 2012ab; Mudgal et al., 2003; Sharma and Jain, 2016). Seasonal green fodders were offered in a limited amount depending upon the availability. A similar feeding pattern was followed after parturition except for the quantity of concentrate portion was increased. Under such a feeding situation, the availability of antioxidant minerals ( $\mathrm{Se}, \mathrm{Cu}$, and $\mathrm{Zn}$ ) and vitamins (vitamin $\mathrm{E}$ and beta-carotene) which are having

How to cite this article: Rathor, A., Jain, R.K., Mehta, M.K. and Keshri, A. (2021). Dietary Micro-Nutrients Supplementation in the Ration of Transition Crossbred Cows Influences the Growth Performance and Hemato-Biochemical Parameters of Newborn Calves. J. Anim. Res. 11(05): 943-945.

Source of Support: None; Conflict of Interest: None 
importance in production and reproduction may greatly be reduced to animals (Spears and Weiss, 2008; Singh et al., 2020). Thus, dairy animals and their calves remain prone to suffer from many problems. Vitamin and mineral supplementation during the transition period improved the performance of newborn calves in terms of their birth weight, immune and antioxidant systems, and body weight gain (Bordignon, et al., 2019). Considering this fact, the present work was planned to study the effect of dietary micronutrient supplementation in the transition crossbred cows on the performance of newborn calves.

Twenty healthy (average body weight $408.25 \pm 12.93 \mathrm{~kg}$ ) advanced pregnant crossbred cows (around the last two months of gestation) reared under similar conditions were selected randomly and divided into two equal groups. Control group cows were fed on the existing ration, while the treatment cows were additionally supplemented with antioxidant nutrients i.e. trace mineral $\mathrm{Cu}$ and $\mathrm{Zn}$ with vitamins $\mathrm{A}$ and $\mathrm{E}$ as per the normal dose of recommendations. Experimental feeding was continued for about two months during advanced pregnancy and followed by two months post-calving. The effect of dietary micronutrient supplementation in transition crossbred cows was assessed by determining the performance of their newborn calves. Parameters considered were the birth weights, fortnightly body weights and some haemato-biochemical parameters like blood glucose, total plasma protein, albumin, globulin, total and differential leucocytes count at about one week of age in six calves from both groups. Birth weight and subsequent weight (at fortnightly intervals) of calves were determined with the help of spring balance $(100 \mathrm{Kg})$ during the period of study.

The mean birth weight of calves was $32.08 \pm 1.55$ and $34.15 \pm 0.88 \mathrm{~kg}$ in cows of the un-supplemented and supplemented group, respectively. Birth weight was higher in supplemented group than the un-supplemented group, although the difference between groups was nonsignificant $(\mathrm{P}=0.06)$. Overall mean body weight $(\mathrm{kg})$ after 60 days was $41.68 \pm 3.10$ and $44.15 \pm 3.34$ in the un-supplemented and supplemented group showed nonsignificant difference between two groups.

In contrast to present findings, Khan et al. (2015) studied that vitamin $\mathrm{E}$ and mineral supplementation during the prepartum period augmenting the improvement in reproductive performance in Murrah buffaloes. They observed that supplementation improved the performance not only of buffalo but also their calves in terms of their birth weight, body weight gain up to 90 days, and calf weight to dam ratio. In contrast to our finding Panda et al. (2006) found a higher average birth weight of calves in the dietary vitamin E (a-tocopheryl acetate) supplemented group than the un-supplemented group. Similarly, when Moeini et al. (2009) studied the effect of dietary vitamin $\mathrm{E}$ and selenium supplementation in cattle during the prepartum period they observed that calf had higher birth weight in the treatment group as compared to the control group. Similar to present findings Modi et al. (2018) when administered injection of vitamin $\mathrm{E}$ and selenium prepartum did not report any effect on the birth weights of calves.

The hematological parameters including hemoglobin, the total count of leukocytes, and differential leukocyte counts are presented in Table 1 . Hemoglobin $(\mathrm{g} / \mathrm{dl})$ values were numerically $(\mathrm{P}>0.05)$ higher in the treatment group $(11.03 \pm 0.70)$ than it was in the control $(9.53 \pm 0.53)$ group. Average values of total leukocyte count $\left(\times 10^{3} \mathrm{~mm}^{-3}\right)$ were $9.64 \pm 0.35$ and $9.01 \pm 0.55$ in the control and treatment groups, respectively. The average percentage values of neutrophils were $34.33 \pm 1.94$ and $29.33 \pm 1.67$, lymphocytes were $63.50 \pm 2.0$ and $68.83 \pm 1.89$, monocytes remained $2.00 \pm 0.68$ and $1.67 \pm 0.33$ in control and treatment groups, respectively and the data did not differ statistically, with similar values of eosinophils $(0.17 \%)$ in two groups.

Table 1: Effect of dietary antioxidant nutrients supplementation to transition crossbred cows affecting haemato-biochemical profile of newborn calves

\begin{tabular}{llll}
\hline Attributes & Control & Treatment & P-Value \\
\hline Glucose (mg/dl) & $90.50 \pm 4.66$ & $96.86 \pm 3.09$ & 0.19 \\
Total protein (g/dl) & $6.09 \pm 0.58$ & $6.43 \pm 0.26$ & 0.19 \\
Albumin (g/dl) & $2.38 \pm 0.09$ & $2.25 \pm 0.12$ & 0.37 \\
$\mathrm{Hb}(\mathrm{g} / \mathrm{dl})$ & $9.53 \pm 0.53$ & $11.03 \pm 0.70$ & 0.33 \\
$\mathrm{TLC}\left(\times 10^{3} \mathrm{~mm}^{-3}\right)$ & $9.64 \pm 0.35$ & $9.01 \pm 0.55$ & 0.25 \\
Neutrophils (\%) & $34.33 \pm 1.94$ & $29.33 \pm 1.67$ & 0.55 \\
Lymphocytes (\%) & $63.50 \pm 2.00$ & $68.83 \pm 1.89$ & 0.72 \\
Monocytes (\%) & $2.00 \pm 0.68$ & $1.67 \pm 0.33$ & 0.10 \\
Eosinophils (\%) & $0.17 \pm 0.00$ & $0.17 \pm 0.00$ & 1.00 \\
\hline
\end{tabular}

Bordignon et al. (2019) evaluated the nutraceutical effect of vitamins and minerals on the performance of dairy calves during the nutritional transition period and reported 
an increase in total leukocyte, DLC, Hb, globulin, and glucose as a result of elevation in neutrophil counts (day 45) and monocytes (days 30 and 45) in the treatment group, but levels of serum copper, selenium, zinc, and manganese were not deficient in these calves. Likewise, Solda et al. (2017) observed the nutraceutical effect of vitamins and minerals on calves and reported an increased number of total leukocytes and decreased levels of $\mathrm{Hb}$ and glucose.

The data about the biochemical profile of cross-bred calves during the experimental period is furnished in Table 1. Results revealed that the blood glucose levels were higher in the treatment group $(96.86 \pm 3.09 \mathrm{mg} / \mathrm{dl})$ than control $(90.50 \pm 4.66 \mathrm{mg} / \mathrm{dl})$, although the difference was non-significant.

Values of total protein $(6.43 \pm 0.26$ Vs. $6.09 \pm 0.58 \mathrm{~g} / \mathrm{dl})$ and globulin (4.18 \pm 0.15 Vs. 3.71 \pm 0.28$)$ also remained numerically $(\mathrm{P}>0.05)$ high in the treatment group as compared to control values and albumin $(\mathrm{g} / \mathrm{dl})$ remained $2.38 \pm 0.09$ and $2.25 \pm 0.12$ in control and treatment groups, respectively.

Bedwal and Bahuguna (1994) found that newborn calves from a selenium-deficient mother suffer from muscular weakness, but the concentration of selenium during pregnancy does not have any effect on the weight of the baby or length of pregnancy. The selenium requirements of a pregnant and lactating mother are increased as a result of selenium transport to the fetus via the placenta and to the infant via breast milk.

\section{CONCLUSION}

The dietary supplementation of micronutrients $(\mathrm{Cu}, \mathrm{Zn}$, vitamin $\mathrm{A}$, and $\mathrm{E}$ ) in the ration of crossbred cows during the transition period was unable to influence the birth weight and subsequent body weights and hematobiochemical parameters of the newborn calves.

\section{ACKNOWLEDGEMENTS}

The authors are thankful to the NDVSU, Jabalpur for the fund for carrying out this research work.

\section{REFERENCES}

Bordignona, R., Volpatoa, A. and Glombow, P. 2019. Nutraceutical effect of vitamins and minerals on performance and immune and antioxidant systems in dairy calves during the nutritional transition period in summer. J. Therm. Biol., 84: 451-459.

Jain, R.K., Saksule, C.M. and Dhakad, R.K. 2012a. Nutritional status and probable cause of hemoglobinuria in advanced pregnant buffaloes of Indore district of Madhya Pradesh. Buff. Bull., 31(1): 19-23.

Jain, R.K., Saksule, C.M., Dhakad, R.K. and Mudgal, V. 2012 b. Nutritional Status of Cows and Buffaloes During Advanced Pregnancy in Indore District of Madhya Pradesh. Indian J. Anim. Nutr., 29 (3): 246-250.

Modi, L.C., Patel, M.D., Khasatiya, C.T., Tyagi, K.K. and Modi, F. 2018. Prepartum administration of vitamin E and selenium injection and its abiding effect on calf weight, placental weight and expulsion time of fetal membrane in Surti buffaloes. Indian J. Anim. Health., 57(2): 195-200.

Moeini, M.M., Karami, H. and Mikaeili, E. 2009. Effect of selenium and vitamin $\mathrm{E}$ supplementation during the late pregnancy on reproductive indices and milk production in heifers. Anim. Reprod. Sci., 114: 109-114.

Mudgal, V., Mehta, M.K., Rane, A.S. and Nanavati, S. 2003. A survey on feeding practices and nutritional status of dairy animals in Madhya Pradesh. Indian J. Anim. Nutr., 20: $217-$ 220

Panda, N., Kaur, H. and Mohanty, T.K. 2006. Reproductive performance of dairy buffaloes supplemented with varying levels of vitamin E. Asian-Australas. J. Anim. Sci., 19(1): 1925

Sharma., P. and Jain, R.K. 2016. Feeding pattern during pregnancy and incidence of reproductive and metabolic disorder in crossbred cows. J. Anim. Res., 6(5): 1-6.

Singh, H.P., Jain, R.K., Tiwari, D., Mehta, M.K. and Mudgal, V. 2021. Strategic supplementation of antioxidant micronutrients in peri-parturient Murrah buffaloes helps augment the udder health and milk production. Biol. Trace Elem. Res., 199(6): 2182-2190.

Spears, J.W. and Weiss, W.P. 2008. Role of antioxidants and trace elements in health and immunity of transition dairy cows. Vet. J., 176(1): 70-6.

Soldá, N., Glombowsky, M., Patrícia, Campigotto, G. and Nathieli, B.B. 2017. Injectable mineral supplementation to transition period dairy cows and its effects on animal health. Vet. Population Medicine, 26(2): 335-342.

Soldá, N.M., Glombowsky, P., Campigotto, G., Bottari, N.B., Schetinger, M.R.C., Morsch, V.M. and da Silva, A.S. 2017. Injectable mineral supplementation to transition period dairy cows and its effects on animal health. Comp. Clin. Pathol., 26(2): 335-342. 
